\title{
STUDY OF CHANGES IN SERUM ELECTROLYTES AND ITS RISK IN DEVELOPMENT OF SENILE CORTICAL CATARACT
}

\author{
Ch. Chandana Chowdary1, V. Sunanda', Y. Jayapal Reddy ${ }^{3}$
}

${ }_{1}^{1}$ Final Year MBBS Student, Kamineni Academy of Medical Sciences and Research Centre, Hyderabad, Telangana, India. 2Professor and HOD, Department of Biochemistry, Kamineni Academy of Medical Sciences and Research Centre, Hyderabad, Telangana, India.

3Professor and HOD, Department of Ophthalmology, Kamineni Academy of Medical Sciences and Research Centre, Hyderabad, Telangana, India.

ABSTRACT
BACKGROUND
Cataract is one of the age-related eye disorders due to the opacity in the lens and accounts for 50\% of blindness in India. Factors
like family history, ageing, alterations in blood electrolytes and diabetes mellitus are involved in formation of senile cataract.
Alterations in serum electrolyte levels can induce alterations in the concentration of electrolytes in aqueous humour, which affect
the lens metabolism and probably lead to the formation of senile cataract.
The aim of the study is to evaluate the effect of the altered levels of serum electrolytes and the risk in development of senile
cataract.

\section{MATERIALS AND METHODS}

Our study was a case control study and included 40 senile cataract patients scheduled for cataract surgery in test group and 40 normal individuals of same age group in control group. A $3 \mathrm{~mL}$ random venous blood sample was collected from all the subjects who enrolled in our study. Serum electrolytes were measured by ISE method (Ion Selective Electrode) using Sensa Core Electrolyte Analyzer. Data was analysed statistically using GraphPad online software. The mean \pm SD of electrolytes were calculated and compared by using paired student $t$-test and $p$-value was elicited. ' $P$ ' value of $<0.05$ was considered as significant.

\section{RESULTS}

The mean $\pm \mathrm{SD}$ of serum $\mathrm{Na}+\mathrm{Cl}$ - in the test group were $143.5 \pm 3.6,102 \pm 3.2$ respectively. Mean $\pm \mathrm{SD}$ of serum $\mathrm{Na}+\mathrm{Cl}$ - in control group were $139 \pm 2.4$ and $100 \pm 2.3$ respectively. The test group had significantly higher $\mathrm{Na}+$ level with 'p' value of $<0.001$ and $\mathrm{Cl}-$ level with ' $p$ ' value of $<0.05$ when compared with control group. Mean $\pm S D$ of serum $\mathrm{K}+$ in test and control group were $3.9 \pm 0.4$ and $4.1 \pm 0.2$ respectively. The test group had significantly lower serum $\mathrm{K}+$ with ' $\mathrm{p}$ ' value of $<0.001$ when compared with control group.

\section{CONCLUSION}

Our study suggests that diet with high sodium, chloride and low potassium remain significant risk factor in development of senile cataract. Salt restricted diet and consumption of diet rich in potassium should be advised in cataract individuals, so as to maintain normal electrolyte balance in order to prevent further progression of the disease.

\section{KEYWORDS}

Serum Electrolytes, Senile Cataract, Na+ -K+ ATPase, Na+ - K+ - Cl- Pump.

HOW TO CITE THIS ARTICLE: Chowdary CC, Sunanda V, Reddy YJ. Study of changes in serum electrolytes and its risk in development of senile cortical cataract. J. Evolution Med. Dent. Sci. 2018;7(27):3115-3118, DOI: 10.14260/jemds/2018/700

\section{BACKGROUND}

Senile cataract is one of the commonest consequences of the ageing process and it affects the normal vision. Senile cataract accounts for about $80 \%$ of blindness in India.(1) Factors such as ageing, family history, undernutrition, altered serum electrolyte levels, diabetes mellitus, hypertension and quality of life are few causes involved in the development of senile cataract. Since metabolism of lens is associated with aqueous humour and this thin fluid itself is a transparent watery fluid similar to plasma, but containing low protein concentration. According to Rewatkar $\mathrm{M}$ et al, the concentration of serum electrolytes directly affects the concentration of electrolytes

'Financial or Other Competing Interest': None.

Submission 27-04-2018, Peer Review 18-06-2018,

Acceptance 23-06-2018, Published 02-07-2018.

Corresponding Author:

Dr. V. Sunanda,

Professor and HOD, Department of Biochemistry,

Kamineni Academy of Medical Sciences and Research Centre,

LB Nagar, Hyderabad-500068, Telangana, India.

E-mail: nandanil1992@gmail.com

DOI: $10.14260 /$ jemds $/ 2018 / 700$ of aqueous humour and in turn affect the lens metabolism.(2)

The concentration of potassium is high and the concentration of sodium is low in the lens. These two cations exchange with each other by the action of Na+-K+-ATPase pump, which affects the permeability of lens capsule. Hence, the change in cation concentration of aqueous humour can be attributed to changes in serum electrolytes. These ultimately affect lens metabolism leading to cataract formation.(3)

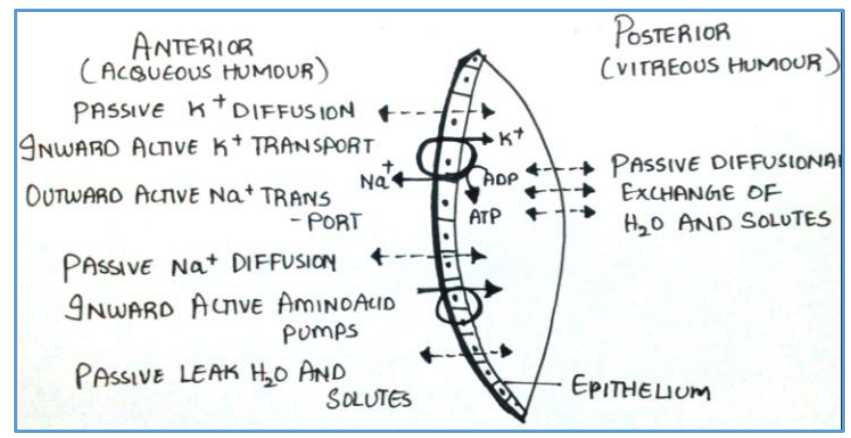

Figure 1 
The normal lens metabolism is based on the 'pump leak theory.' It is a combination of active transport and membrane permeability. Lens epithelium is a site of active transport of $\mathrm{Na}+-\mathrm{K}+-$ ATPase and $\mathrm{Ca}+-$ ATPase. $\mathrm{K}+$ and amino acids are actively transported and diffuse out through back of the lens. $\mathrm{Na}+$ flows from back of the lens and is exchanged with $\mathrm{K}+$ in the epithelium.

Fig. 2- Chemical composition of the lens vis-a-vis aqueous humour and chemical exchange between them. Values in $\mathrm{mmol} / \mathrm{kg}$ of lens(1):

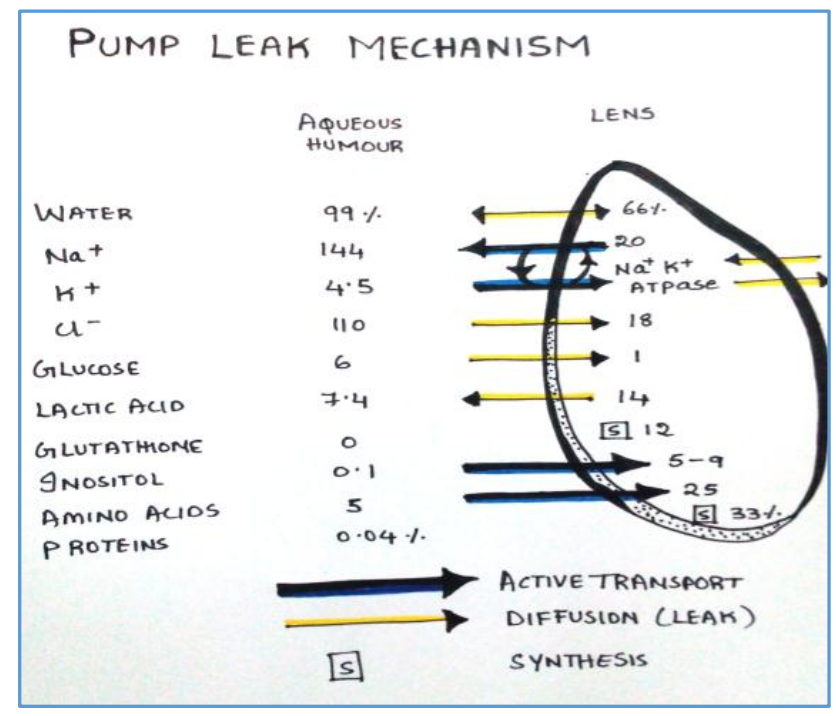

Figure 2

The permeability of chloride is high in lens. Chloride enters into the lens by passive diffusion. A disturbance in the chloride concentration or chloride handling by the lens will jeopardise the ability of the lens to maintain its hydrated state and threaten a loss of osmotic equilibrium that may result in cataract.(3) Our study is aimed to estimate the effect of altered serum electrolyte levels in development of senile cataract.

\section{MATERIALS AND METHODS}

Our study is conducted in the Department of Biochemistry with the collaboration from the Department of Ophthalmology in Kamineni Academy of Medical Sciences and Research Centre, LB Nagar, Hyderabad, Telangana state. It is a case control study. The total study population consisted of 80 individuals and the sample size was taken as per our convenience. (This study was conducted as short term project for Final MBBS- Part I students during summer vacation)-

Group 1- 40 Senile cataract patients of age between 50 - 80 years.

Group 2- 40 Individuals (without senile cataract) of same age group.

The Study was approved by the Institutional Ethical Committee.

Informed Consent was obtained from all the Participants

1. Patients diagnosed as senile cortical cataract (pearly white opacity) by slit lamp examination were taken as cases who were attending the OPD of Department of
Ophthalmology in Kamineni Hospital, LB Nagar, Hyderabad.

2. Individuals without having senile cataract and attending the OPD of Ophthalmology, Kamineni Hospitals, within the age between 50 - 80 years as controls.

\section{Inclusion Criteria}

1. Age group in between 50 - 80 yrs.

2. Both males and females.

\section{Exclusion Criteria}

1. Not willing to participate in the study.

2. Cataract due to any other aetiology like trauma, radiation, diabetes mellitus, hypertension etc.

3. Patients with asthma, acute or chronic renal failure, any history of drug intake like antipsychotics, chemotherapy etc.

Random venous blood sample of $2 \mathrm{~mL}$ was collected from all the participants included in this study in plain vacutainer and allowed to clot for 30 minutes. Serum was separated by centrifugation of the sample at $3000 \mathrm{rpm}$ for 10 minutes and electrolyte levels $(\mathrm{Na}+, \mathrm{K}+$ and $\mathrm{Cl}-$ ) were analysed by Ion Selective Electrode method using Sensa Core Electrolyte Analyzer.

\section{Statistical Analysis}

The mean \pm SD values of all the electrolytes were calculated by GraphPad online software. The comparison of serum electrolytes was done by paired student ' $t$ ' test. Interpretation was done according to ' $\mathrm{p}$ ' value. ' $\mathrm{P}$ ' value $<0.05$ was significant statistically.

\section{RESULTS}

The mean $\pm \mathrm{SD}$ of serum $\mathrm{Na}+$ is $143.5 \pm 3, \mathrm{~K}+$ is $3.9 \pm 0.4$, Cl- is $102 \pm 3.2$ in Group I, that is the test group. The mean \pm SD of serum $\mathrm{Na}+$ is $139.7 \pm 2.4, \mathrm{~K}+$ is $4.1 \pm 0.2$, $\mathrm{Cl}$ - is $101 \pm 3.2$ in Group II that is the control group. Serum $\mathrm{Na}+$ and $\mathrm{Cl}-$ were found to be statistically higher $(143.5 \pm 3.6,102 \pm 3.2)$ and serum $\mathrm{K}+$ (3.9 \pm 0.4$)$ was lower in Group I as compared to Group II (Na+: $139 \pm 2.4, \mathrm{Cl}-:$ : $101.2 \pm 2.3, \mathrm{~K}+: 4.1 \pm 0.2$ ), though electrolyte levels did not cross the upper level of reference limit.

\begin{tabular}{|c|c|c|c|}
\hline Analytes & $\begin{array}{c}\text { Group-1 } \\
\text { (Test Group) } \\
\text { n=40 Mean } \pm \text { SD }\end{array}$ & $\begin{array}{c}\text { Group-2 } \\
\text { (Control Group) } \\
\mathbf{n = 4 0} \text { Mean } \pm \text { SD }\end{array}$ & 'P' value \\
\hline Serum $\mathrm{Na}+$ & $143.5 \pm 3.6$ & $139.7 \pm 2.4$ & $<0.001$ \\
\hline Serum $\mathrm{K}+$ & $3.9 \pm 0.4$ & $4.1 \pm 0.2$ & $<0.001$ \\
\hline Serum $\mathrm{Cl}-$ & $102 \pm 3.2$ & $101.2 \pm 2.3$ & $<0.05$ \\
\hline Table 1. Showing Mean \pm SD of Electrolytes in both the \\
Groups \\
\hline
\end{tabular}

'P' value $<0.05=$ statistically significant, ' $\mathrm{p}$ ' value $<0.001=$ statistically highly significant.

Normal serum Sodium: 135 - $145 \mathrm{mmol} / \mathrm{L}$

Normal serum Potassium: 3.5 - $5.5 \mathrm{mmol} / \mathrm{L}$

Normal serum Chloride: 96 - $108 \mathrm{mmol} / \mathrm{L}^{(4)}$

\section{DISCUSSION}

Cataract is the utmost cause of defective vision and blindness in the world with an estimated 17 million individuals are bilaterally blind.[5] The WHO and international agency for prevention of blindness have formulated a worldwide 
initiative "vision 2020 - the right to sight" for elimination of avoidable blindness by the year 2020 .

The incidence of senile cataract is increasing with age, which accounts for more than $50 \%$ of all cases of cataract. Important risk factors for senile cataract include ageing, electrolyte imbalance, diabetes mellitus, hypertension, nutrition, family history and exposure to UV radiation. Normally, lens has high level of $\mathrm{K}+(114-130 \mathrm{mmol} / \mathrm{L})$ and low $\left.\mathrm{Na}+(14-26 \mathrm{mmol} / \mathrm{L}) .{ }^{6}\right)$ These two cations are in balance with each other, because of $\mathrm{Na}+-\mathrm{K}+-$ ATPase pump, which in turn maintains permeability of lens membrane. The membrane permeability of the lens is increased with age due to reduced activity of $\mathrm{Na}+-\mathrm{K}+\mathrm{ATPase}$ pump, which leads to an increase in the internal $\mathrm{Na}+$ concentration. Higher levels of extracellular $\mathrm{Na}+$ might make it more difficult for $\mathrm{Na}+-\mathrm{K}+$ ATPase pump to maintain the low levels of intracellular $\mathrm{Na}+$ required for lens transparency. In addition to this alteration in $\mathrm{Cl}$ - levels have also been suggested for the possible mechanism of cataract development by causing of osmotic equilibrium.(7)

Patients included in the present study were devoid of diseases like diabetes mellitus, acute or chronic renal failure and conventional risk factors for cataract formation like high blood glucose and urea were not present in these patients. Therefore, role of serum electrolyte imbalance can be justified in the process of cataract formation.(8)

According to Pravin N Soni et al, they have observed that there is a remarkable difference in sodium concentration of aqueous humour in turn and this can be one of the important risk factors in the formation of cataract.(8) According to Mansour Mirasamadi et al, studied in Iranian population showed that the mean of serum $\mathrm{Na}+$ was in normal range (upto the upper limit of normal range) in senile cataract patients and when compared with control group the serum $\mathrm{Na}+$ of these patients were significantly increased. But serum potassium did not show any significant difference.(9,10) In spite of this in other studies such as the Italian-American study, no relation between blood biochemical elements and cataract has been shown. This contrast may be due to nutritive quality and different diets in nations all over the world.(11) We have found in our study that there is significant elevation in serum sodium and chloride concentrations and a depletion in serum potassium concentration in Group 1 individuals as compared to healthy controls. Elevation in sodium levels is in accordance with the studies by Rewatkar et al and Mathur et al.(12,13) Diet with high sodium concentrations may be a risk factor for the causation of cataract in elderly aged population. Hence, after 50 years of age, serum electrolytes measurement is one of the screening investigation which can predict early development of senile cataract. It is also a critical issue, because most of the electrolyte changes are silent and one-half of all cataract cases occur among individuals with normal serum electrolyte levels.

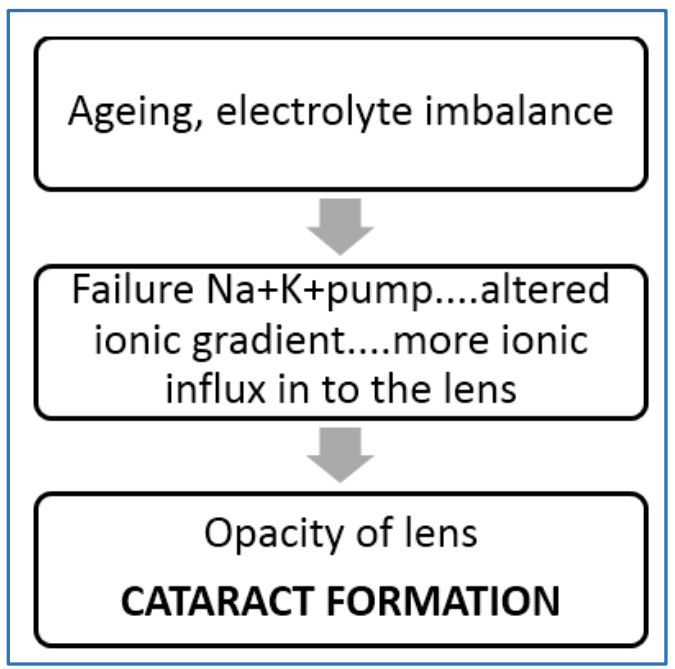

Figure 3. Flow Chart depicting the Formation of Cataract

\section{CONCLUSION}

We conclude from our study that the biochemical parameters like serum electrolytes $(\mathrm{Na}+, \mathrm{K}+, \mathrm{Cl}-)$ can act as modifiable risk factors in age related cataract. Hence, diet rich in $\mathrm{Na}+$ has to be avoided along with consumption of diet rich in $\mathrm{K}+$. It has to be advised in early cataract individuals to delay the progression of cataract.

\section{Limitation of Study}

1. Sample size is small.

2. Setting of study in a tertiary care centre.

3. Larger prospective longitudinal population-based studies are required to categorically ascertain this association of altered levels of serum electrolytes with senile cataract.

\section{REFERENCES}

[1] Khurana AK, Khurana AK, Khurana B. The Lens. Comprehensive Ophthalmology. $6^{\text {th }}$ edn. New Delhi: Philadelphia: Jaypee, The Health Sciences Publisher 2015: p. 179-84.

[2] Upadya UB, Sumana BA, Parveen D, et al. Study of electrolytes in cataract patients. International Journal of Current Medical and Pharmacological Research 2017;3(1):1216-8.

[3] Zhang JJ, Jacob TJC. The role of chloride in the lens of the eye. Experimental Physiology 1997;82(2):245-59.

[4] Shakil M, Ahmed ST, Samiullah SM, et al. Influence of hypertension and diabetes mellitus on senile cataract. Pak J Physiology 2008;4(2):30-2.

[5] Singh R, Tendon R. The lens. Parson's diseases of eye. $22^{\text {nd }}$ edn. Elsevier - A Division of Reed Elsevier India Pvt Ltd., 2015: p. 262-5.

[6] Cumming RG, Mitchell P, Smith W. Dietary sodium intake and cataract: The Blue Mountains Eye Study. American Journal of Epidemiology 2000;151(6):624-6. 
[7] Soni PN, Chabada DS, Wankhede SU, et al. Serum electrolyte changes in senile cataract patients at tertiary care teaching hospital in Marathwada region, Maharashtra, India. International Journal of Advances in Medicine 2016;3(2):287-90.

[8] Adiga US, Harris A, Ezhivathani, et al. Serum electrolytes in senile cataract patients. US National Library of Medicine Enlisted Journal. Al Amen J Med Sci 2014: p. 160.

[9] Kumar JPM, Harim SM, Meghna MA, et al. Comparitive study of $\mathrm{Na}+\mathrm{K}+$ levels in senile cataract patients. SEAJCRR 2013:190-6.

[10] Schoenfeld ER, Leske MC, Wu SY. Recent epidemiologic studies on nutrition and cataract in India, Italy and the United states. Journal of American College of Nutrition 1993;12(5):521-6.
[11] Rewatkar M, Muddeshwa MG, Lokhande M, et al. Electrolyte imbalance in cataract patients. Indian Medical Gazette 2012:89-91.

[12] Mathur G, Pai V. Comparison of serum sodium and potassium levels in patients with senile cataract and age matched individuals without cataract. Indian J Ophthalmol 2013;59:141-2.

[13] Vasudevan DM, SreeKumari S, Vaidyanathan K. Reference values. Text book of biochemistry for medical students. $8^{\text {th }}$ edn. Jaypee Brothers Medical Publishers (P) LTD., 2016: p. 692. 